\title{
Analysis of Parental Opinions on Sound and Noise Pollution in Learning Environments*
}

\author{
Mizrap BULUNUZ1 $\quad$ Kerime ÖZGÜR²
}

\begin{abstract}
The aim of this study is to examine parents' views on noise at home and at school. Seventy-seven parents who know their children's school, such as class representatives and class mothers, and who are closely interested in the education of their children, participated in the study. Questionnaire and observations of the researcher were used as data collection tools. The "Sound and Noise Questionnaire in Learning Environments" is the basic data collection tool. The data were analyzed descriptively. The results show that children are exposed to various noises such as loud talking, kitchen appliances, vacuum cleaners and TV sound while studying at home. It has been revealed that some families do not try to reduce the noise in the house while their children are studying. It is understood that nearly half of the parents have insufficient awareness of the psychological and physiological discomfort caused by noise. The rate of parents who do not make a rule about keeping the environment quiet, while children are studying, is $14.7 \%$. Almost $40 \%$ of the parents find the noisy behaviors of children during school break appropriate. On the other hand, about $60 \%$ of the parents are of the opinion that the noise in the school is distracting, and the noise they are exposed to is disturbing. Parents do not have a consensus on preventing noise at school. There is a need to increase the awareness of parents about the negative effects of noise. Most of the parents stated that they would support the acoustic improvements to be made at the school. It has been observed that parents have great excitement, interest, and curiosity about noise in learning environments by asking questions to the researcher regarding the survey questions. Just filling out a questionnaire has drawn parents' attention to noise in their learning environment. In order to create quieter learning environments at home and at school, and to sprout a culture of tranquility in social life, parents should be included in projects to reduce noise.
\end{abstract}

Keywords: Noise at home, noise survey, noise in school, parental views.

\section{Introduction}

Studies show that the noise level in schools is well above the limit values determined in the regulation (Bulunuz et al., 2018; Özbıçakçı et al., 2012; Tamer-Bayazıt et al., 2011). There are two main reasons for the high noise level in the school. First, schools are built without acoustic design and equipment; second is a lack of awareness, sensitivity and awareness about noise pollution in school and social life. Since the acoustics of school buildings fall within the domain of engineers, this study will focus on the noisy

\footnotetext{
* This study was supported by TUBITAK(1001) program, project numbered 114K738 and titiled "Noise Pollution in Sschool: Causes, Effects and its Control." The study was produced to increase the dissemination of the project at the parental dimension.

${ }^{1}$ Bursa Uludag University, Faculty of Education. mizrap@uludag.edu.tr, ㄴ https://orcid.org/ 0000-0002-6650-088X

${ }^{2}$ Bursa Uludag University, Institute of Educational Sciences. kerime.ozgur@gmail.com, 는 https://orcid.org/0000$\underline{0002-1371-0437}$
} 
culture that surrounds schools and social life. In the school building, students' shouting, running, slamming doors and tugging at desks, high school bells, teachers' warnings of students by shouting, banging or blowing a whistle can be listed as examples of the noisy culture in the school. Similarly, the noises of neighbors in the apartment, traffic noise, shouting sales by marketers, loud conversations in public transportation vehicles and loud music in entertainment venues are examples of noises originating from social life. Richard Dawkins (1995) in his book "The Selfish Gene" states that there are two things in the world that have the ability to self-replicate. One of them is gene and the other is culture. Unfortunately, this noise culture has emerged in our society, and it is constantly copying itself and is growing like an avalanche in almost every field (Çetinkaya et al., 2017; Polat \& Buluş-Kırıkkaya, 2004; Sezgin \& Mutlu, 2017; Tamer-Bayazit et al., 2011; Tüzel, 2013). Therefore, noise is a deeply rooted problem that must be taken very seriously. Nobel Prize-winning German bacteriologist Robert Koch (1910) stated that a century ago, noise was a means of death that slowly killed it like smoke, and that one day people will fight against noise like cholera and plague (Koch, 1910 cited in Vijayalakshmi, 2003). Koch's prediction has come true today. Acoustic engineers conduct research on how to create peaceful environments in all areas of social life, from vehicles to offices, homes and schools (Bulunuz et al., 2018; Coşkun, 2021; Dockrell \& Shield, 2004; Klatte et al., 2010; Shield \& Dockrell, 2003; Shield \& Dockrell, 2004; Shield \& Dockrell, 2006). But is this enough? Can noise be prevented with only engineering solutions?

As stated above, noise is an important social problem with dangerous and cultural dimensions. Cüceloğlu (2019c) emphasizes that people live in an ocean of culture just as fishes live in the ocean and that many messages, behavioral patterns, beliefs, and values are taught to individuals over time without realizing it. How culture shapes the behaviors of individuals is expressed as follows: The traditions, customs and culture of the society in which the individual grows up and lives play an important role in shaping human behavior. Culture reinforces certain kinds of behaviors as desirable, appropriate, and liked behaviors, while vilifies, humiliates others, and thus extinguish over time. For this reason, culture brings an extremely powerful and widespread social reinforcement order (Cüceloğlu, 2019b, 154). As it is understood from here, every society has a certain culture that it has created over time. This culture rewards or punishes the behavior of people living in that society within a certain social value system. Thus, a social order that protects certain values is established. It is very difficult to be noticed because it contains values, assumptions and beliefs learned through a culture lived in noise or silence. For this reason, in our country where the culture of noise and fuss is common, noise exposure at school and in social life is often not perceived as a problem. Because, starting from home, individuals who grow up in the culture of noise and fuss in school and social life are accustomed to noise since there is no other ground to make a difference in their perception. So, this situation is starting to be accepted as normal. Therefore, it is extremely important to reveal the existing perceptions and awareness of parents about noise, starting with the family. Dökmen (2019) defines noticing as a state of consciousness. In order for a stimulus to be noticed, it must reach the sense organs and be strong enough to exceed a certain threshold. However, this is not enough. In addition, the incoming stimulus should be associated with the existing schemes in the mind, defined, and felt the desire to engage in emotional experience and communication with the stimulus (Dökmen, 2019, 102-103). "We do not notice something within us that does not arouse any excitement/emotion; even if we look at it, we probably wouldn't notice it" (Dökmen, 2019, 104). Awareness is a cognitive and affective activity. When these two activities come 
together, new mental schemas are formed. Creating new schemas means expanding the field of consciousness. By becoming aware, our consciousness level about ourselves, our environment and the universe increases, and our field of consciousness expands (Dökmen, 2019, 104). Noticing physical stimuli around us can contribute to our more effective existence. In order to learn and adapt to the outside world, it is necessary to notice first. This is the first step in turning to new possibilities and protecting from dangers (Dökmen, 2019, 105). Cüceloğlu (2019d, 96) stated that there are three types of awareness dimensions in individuals according to the situation they are in. First, not being aware of the situation at all; secondly, to be aware of the situation, but not to know why it is in such a situation; the third is to be aware of the situation and its cause. It is difficult for a person who grew up in a noisy environment at home, at school and on the street to perceive the negative effects of noise and to struggle against it. For this reason, in order to combat the noise that has spread to all areas of social life, the awareness of individuals to observe the knowledge, beliefs and values transferred by culture should be activated (Cüceloğlu, 2019c). After raising awareness about the causes and effects of the noise problem in the school and in the society, starting from individuals, societies will either accept to live at a level that will negatively affect human health or will be faced with the option of developing interests, beliefs and values for a quiet life. If we do not do this, the beliefs, values, and knowledge that the existing noisy culture offers will continue to be accepted. Cüceloğlu (2016) stated that awareness is the essence of life and that people can only choose among the things they are aware of. The only way to get rid of the noisy school and social life is to realize the noise culture and to carry out educational activities to create a quiet culture. For this, the reality of quiet family, school and social life must be perceived and participated in life, going beyond the reality, beliefs and values that exist in society in terms of noise.

Whether at school or at home, it is important for the child to learn their limits and sense of responsibility. In order for students to take responsibility for the school to be quiet, they must have awareness and consciousness of the noise and noisy behaviors for which they will be held responsible. When it comes to holding students accountable, the emphasis is on teaching that is not based on fear. According to Cüceloğlu (2019b), it is possible to provide responsibility and discipline with something valued. Because people also act to protect something they know valuable (Cüceloğlu, 2019c, 167). In the culture of fear, the rules are set without discussion, they are not open to discussion and development. In the culture of values, on the other hand, the rules are open to discussion, development and change. Rules should be set in order to create an environment that will better develop the essence of the child (Cüceloğlu, 2019a, 175). "A school administrator has the power to influence teachers, students and their families" (Cüceloğlu, 1998, 94). While setting the rules to create peaceful learning environments at school and at home, participation should be ensured by making various activities suitable for children's learning, discussing, and explaining, and rules should be set. According to Cüceloğlu (2019a), there is no room for arbitrariness in the culture of values. Whether the parent, teacher, or administrator in the position of authority, they have to comply with the rules and values that the child must comply with and be accountable (Cüceloğlu, 2019a, 176-177). For example, teachers who warn students by banging on the table or whistling, principals who make the school groan with loud bells, and parents who watch TV loudly while their child is studying at home, need to correct their mistakes, such as students making noise in school by shouting, running, and playing games. Such corrections are necessary for a quieter, calmer, peaceful and secure life at school and at home. If we want to teach children a behavior, we must first set a good example ourselves. Otherwise, the child begins to doubt the validity of the information 
given and our reliability (Cüceloğlu, 2019a, 42). While parents who gain awareness about noise will set rules for their children, they will also avoid noisy behaviors at home. Peaceful living and learning environments in society should take their place among important values. It should be known that under this important value lies protecting the physiological and psychological health of people and supporting the academic success of students by creating a suitable climate for learning.

Cloud and Townsend (2018) explain the importance of setting limits to children without being harsh, intimidating or embarrassing in their book titled "Boundaries with Kids". In the book, it is stated that children are not born with borders, that the border is the property line that includes a person, and this line is determined by the line where one person ends, and another person begins. They internalize boundaries through external relations and discipline. In order for children to be responsible, families need to set clear boundaries for them and establish a relationship that helps children learn their limits. If the boundaries are clear enough, children develop the following characteristics: a well-defined sense of self, the ability to see their responsibilities, the ability to choose, the understanding that everything will be fine if they make good choices, they will suffer if they make the wrong choices, and the understanding that there is a possibility of true love based on freedom (Cloud \& Townsend, 2018, 23). When children know where their boundaries begin and end at home and at school, they can begin to take control of their emotions, attitudes, and behaviors. "Your role as a parent is to help your child develop within himself what you offer from the outside, such as responsibility, self-control, and freedom. Setting boundaries and maintaining them is no easy task. But when the right formula is applied, it really works" (Cloud \& Townsend, 2018, 7). Learning boundaries is closely related to experiencing the consequences of behavior, learning to own one's life, and dealing with others' boundaries (Cloud \& Townsend, 2018). All the stakeholders in the school complain about the noise pollution in the school. But when it comes to who caused the noise, everyone avoids taking responsibility. Stakeholders in the school should clearly explain what they expect from each other in their communication and relationships. Then, the parties should be expected to take responsibility for their respective roles (Cloud \& Townsend, 2018). A child should know what his responsibilities are for a quiet study environment at home and at school, and why he should take responsibility for this. Children should know that a calmer learning environment contributes to their mental development and success in their lessons. If children know that they need to take responsibility for these, they learn to comply with these conditions and exhibit the behaviors that this requires (Cloud \& Townsend, 2018).

A parent or guardian is defined as the person who protects a child, takes care of their affairs and is responsible for all their behaviors (Turkish Language Institution [TDK], 2020). According to the Ministry of National Education (2014), parent refers to the mother or father of the student or the person who takes legal responsibility. From these definitions, the parent is the person who has assumed the legal responsibility of the students and will be the first to be addressed for all his behavior in the school. Considering that students spend more time at home than at school, it is obvious that the learningteaching process needs to be supported or overlapped with their home life (Yllmaz \& Öznacar, 2016). Otherwise, it will be difficult to achieve the educational goals. For an effective school education, home and school should complement and integrate each other (Şimşek \& Tanaydın, 2002). Hollingsworth and Hoover (1999) refer to parents as children's teachers at home because they directly or indirectly educate children at home. Educational Philosopher John Dewey (2017), with his masterpiece "School and Society", revealed at the beginning of the 19th century that school and family should be considered as a 
whole because education starts in the family and the family is the smallest building block of society. In this context, if we want to create a quieter, calmer and more peaceful school and society, the starting point is undoubtedly family and school. For this reason, when dealing with the noise problem at school, it is absolutely necessary to involve the family in the work to be done. Schools are buildings whose main purpose is to educate students. In terms of the needs of students and teachers at school, the basic need is to provide verbal communication completely and uninterruptedly. Acoustic comfort conditions must be good for the effectiveness of communication or the intelligibility of speech. For this reason, the acoustic environment of schools should be an environment where children can communicate comfortably and hear their teachers. However, showing that the noise level in the school has reached approximately twice the $39 \mathrm{~dB}$ level specified in the "Regulation on the Protection of Buildings Against Noise" (2017) (Bulunuz et al., 2018; Bulunuz, 2014; Özbıçakçı et al., 2012; Tamer-Bayazıt et al., 2011), there are many studies examining various dimensions of noise such as acoustic improvement, student and teacher opinions (Alp et al., 2019; Bulunuz et al., 2017a; Bulunuz et al., 2017b; Bulunuz \& Bulunuz, 2017; Bulunuz et al., 2018). However, when the literature is examined, no research has been found on the views of parents or guardians on sound and noise pollution in learning environments in our country. Considering that parents are an integral part in the formation of the school's climate and culture, their awareness of sound and noise is very important in order to create peaceful learning environments. The aim of this research is to reveal the views of parents on the causes, effects and control of noise at school and at home. For this purpose, answers to the following questions were sought: 1- What are the parents' views on the level of noise exposure at home and its causes? 2- What are the views of parents on the effects and control of noise exposure at home? 3- What are the parents' views on the level of noise exposure at school and its causes? 4- What are the views of parents on the effects of noise exposure at school and its control?

\section{Method}

\section{Model of the Research}

The research was carried out according to the survey research model. Survey research is the analysis of participants' views on a subject or event, or their interests, skills, abilities, attitudes, etc. It is generally referred to as studies conducted on larger samples than other studies in which the characteristics of the research are determined (Büyüköztürk et al., 2016). In survey research, a part of a large population consisting of people who can represent the community is selected to describe the views or characteristics (belief, knowledge, attitude, anxiety, interest, etc.) on a subject. The process of collecting the data needed for the research is based on the answers to the questions posed to the data sources. The data are collected from a sample representing this community, not from each individual of the community whose characteristics will be described (Fraenkel \& Wallen, 2006 cited in Büyüköztürk et al. 2016, 177). In this study, it was tried to evaluate the opinions and behaviors of parents about noise at home and at school.

\section{Sample of the Research}

The sample of the study consists of 77 participants selected among the parents of students studying in a primary school located in the city center of a city in the Marmara Region. The socio-cultural structure of 
the place where the sample is located is medium and low. It is a settlement area that receives immigration and industrialization. In the research, the words parent and guardian will be used synonymously. In the determination of the sample, priority was given to the selection of the parents, whose room mother or representative, actively involved in the activities of the school parent associations. Demographic information of the parents is presented in Table 1.

\section{Table 1}

Demographic Variables Regarding Parents

\begin{tabular}{|c|c|c|c|}
\hline Variables & Options & $\mathrm{n}$ & $\%$ \\
\hline \multirow[t]{2}{*}{ Gender } & Female & 71 & 92.20 \\
\hline & Male & 6 & 7.80 \\
\hline \multirow[t]{4}{*}{ Age } & $25-30$ & 18 & 24.0 \\
\hline & $31-35$ & 29 & 38.70 \\
\hline & $36-40$ & 26 & 34.60 \\
\hline & $41-45$ & 2 & 2.70 \\
\hline \multirow[t]{4}{*}{ Number of children } & 1 & 14 & 18.90 \\
\hline & 2 & 52 & 70.30 \\
\hline & 3 & 7 & 9.50 \\
\hline & 4 & 1 & 1.40 \\
\hline \multirow[t]{2}{*}{ Marital status } & The married & 77 & 100.0 \\
\hline & Divorced & - & - \\
\hline \multirow[t]{6}{*}{ Educational Status } & Primary school & 3 & 9.10 \\
\hline & Primary education & 4 & 5.20 \\
\hline & Middle School & 18 & 23.40 \\
\hline & High school & 28 & 36.40 \\
\hline & College & 8 & 0.40 \\
\hline & License & 16 & 20.80 \\
\hline \multirow[t]{6}{*}{ Working Status } & Public sector employee & 13 & 6.90 \\
\hline & Self-employment & 7 & 9.10 \\
\hline & Housewife & 34 & 44.20 \\
\hline & Private sector employee & 12 & 15.60 \\
\hline & Not working & 5 & 6.50 \\
\hline & Other & 6 & 7.80 \\
\hline \multirow[t]{4}{*}{ Monthly Income } & Low & 8 & 10.40 \\
\hline & Middle & 47 & 61.0 \\
\hline & Good & 20 & 26.0 \\
\hline & Very good & 2 & 2.60 \\
\hline
\end{tabular}


As can be seen in Table 1, the majority (92.2\%) of the parents participating in the study are women. Parents are the lowest 25 years old and the highest 43 years old. The average age is 34 . All of the parents participating in the study are married. Considering the number of children they have, the highest rate $(70.3 \%)$ is with two children. Education levels are generally at the secondary and high school level. Considering the working status of the parents participating in the research, it is understood that almost half $(44.2 \%)$ are housewives. In terms of income level, the participants are mostly in the middle- and low-income level.

\section{Data collection tool}

In the study, a questionnaire was applied to collect data. The researchers collected the data with questions that they would read and answer directly from the parents (MEGEP, 2006; Seyidoğlu, 2000). Care was taken to ensure that the questions were short, clear and precise so that everyone could understand them in the same way. In the preparation of the survey questions, the knowledge and data collection tools of the project carried out on noise pollution at school (Bulunuz et al., 2018) were used. In the preparation of the questionnaire, studies on noise in the national and international literature were scanned and items were created (Goines, 2008; Shield \& Dockrell, 2004:2006; Tamer-Bayazit et al., 2011). "Sound and Noise Parent Questionnaire in Learning Environments" consists of two parts. The first part includes the gender, age, education level, number of children, income level, etc. of the parents. It consists of a "General Information Form" with 14 questions containing demographic information. The second part consists of a total of 44 questions, mostly with two, three and five options, prepared for parents' noise level at home and at school, noise sources, effects and control. 4 questions about indoor noise; 3 questions about noises originating from outside the home; 17 questions about dealing with noise; 20 questions were asked about sound and noise in their children's school. Most of the questions have five options. For example, two-choice questions are the type of questions that reveal whether there is noise and then question what level it is. In order to determine the content, clarity and response time of the items related to the questionnaire, first a pilot application and then the main study were carried out. This pilot study was presented as an oral presentation and published in the congress proceedings book (Bulunuz et al., 2019). The entire questionnaire is presented in Appendix 1.

\section{Data Analysis}

In this research, the "General Information Form" created to collect demographic information such as parents ' gender, age, educational status, number of children, income level was included on the first page of the survey. The opinions of the parents on the noise level at home and at school, noise sources, effects and control were obtained with the Sound and Noise Questionnaire in Learning Environments. In this study, SPSS 22.0 program was used in the analysis of quantitative data. By reviewing the survey data, frequency and percentage calculations were made through quantitative analysis and related tables were interpreted.

\section{Findings}

In this section, firstly, the frequency tables of the answers to the questions in the general information form in the questionnaire will be presented. Then, the findings obtained for each research question will be examined in four sections, respectively. According to the data collected from the questionnaire 
information form, the study was carried out with mostly low and middle socioeconomic level parents in the selected sample. The fact that the education level of the parents is mostly at primary and high school level, that the majority of them are unemployed and housewives, and that they are at a medium and low level in terms of income are proof of this. In this respect, it can be said that the study was carried out with a sample representing the majority of the Turkish society. The frequency and percentage values of the answers given by the parents to the questions in the General Information Forum are shown in Table 2 .

Table 2

Answers to the Questions in the General Information Form of the Parents

\begin{tabular}{llll}
\hline Items & Options & F & $\%$ \\
\hline The existence of a rule about the sound level when & Yes & 65 & 85.50 \\
speaking in the family & No & 11 & 14.50 \\
\hline The person who sets the rules in the house & I & 6 & 7.80 \\
& My partner & 4 & 5.20 \\
& My wife and me & 50 & 64.90 \\
\hline The state of obedience to the rules of the house by & Kids. wife and I & 17 & 22.10 \\
everyone & Yes & 64 & 85.30 \\
\hline The presence of the child's own room & No & 11 & 14.70 \\
\hline Situation of the child studying his lessons in his own & Yes & 68 & 88.30 \\
room & No & 9 & 11.70 \\
\hline The situation of creating a suitable study environment & Yes & 52 & 69.30 \\
for your child at home & No & 23 & 30.70 \\
\hline Noise disturbs but does not harm human health. & I agree & 73 & 94.80 \\
\hline
\end{tabular}

As can be seen in Table 2, 65 (85.5\%) of the parents who participated in the research stated that they had a rule about the sound level while speaking in the family, while $11(14.5 \%)$ did not. This result shows that they took precautions to control the noise. $50(64.9 \%)$ of the parents reported that they mostly determined the rules at home together with their spouses. This result shows that more parents have a say in determining the rules in the family. $64(85.3 \%)$ of the parents stated that the rules at home were followed by everyone. $68(88.3 \%)$ of the parents who participated in the research stated that their child had their own room, $52(69.3 \%)$ of them said that their children studied in their own room, $73(94.8 \%)$ of them stated that a suitable study environment was created for their child at home. reported. "Noise disturbs, but does not harm human health." The rate of those who agree with the article and those who are undecided and the rate of those who do not agree is half. "Noise disturbs, but does not harm human health." The total number of parents who agree with the item and are undecided is $38(49.4 \%)$. This result shows that the parents participating in the study do not have knowledge about the psychological and physiological negative effects of noise on people or their awareness is insufficient. 


\section{Views on the Level and Causes of Noise at Home}

The first sub-problem of the study was determined as "What are the parents' views on the level of noise exposure at home and its causes? The findings of this problem are given in Table 3.

Table 3

Views on the Level and Causes of Noise Exposure at Home

\begin{tabular}{|c|c|c|c|}
\hline Items & Options & $\mathrm{F}$ & $\%$ \\
\hline Proportion of household noise & None & 9 & 11.80 \\
\hline \multirow[t]{3}{*}{ made by children } & Some & 45 & 59.20 \\
\hline & The vast majority & 20 & 26.30 \\
\hline & All & 2 & 2.60 \\
\hline The situation of having problems & Yes & 27 & 35.10 \\
\hline caused by the noise in the house & No & 50 & 64.90 \\
\hline \multirow[t]{6}{*}{ Other sources of noise in the house } & Noises made by children in the & 36 & 48.0 \\
\hline & house & & \\
\hline & Refrigerator, air conditioner, & 18 & 24.0 \\
\hline & washing machine, dishwasher & & \\
\hline & $\mathrm{TV}$, computer, aquarium, clock & 17 & 22.70 \\
\hline & Other & 4 & 5.30 \\
\hline \multirow{2}{*}{$\begin{array}{l}\text { Having problems with outside } \\
\text { noises at home }\end{array}$} & Yes & 32 & 41.6 \\
\hline & No & 45 & 58.4 \\
\hline \multirow[t]{6}{*}{ The most annoying noise } & Noises made by children in the & 22 & 29.30 \\
\hline & house & & \\
\hline & Refrigerator, air conditioner, & 19 & 25.30 \\
\hline & washing machine, dishwasher & & \\
\hline & TV, computer, aquarium, clock & 29 & 38.70 \\
\hline & Other & 5 & 6.70 \\
\hline \multirow{2}{*}{$\begin{array}{l}\text { Having problems with outside } \\
\text { noises at home }\end{array}$} & Yes & 32 & 41.60 \\
\hline & No & 45 & 58.40 \\
\hline \multirow[t]{5}{*}{ Noises from outside } & Traffic noise & 43 & 59.70 \\
\hline & Noise from downstairs and upstairs & 15 & 20.80 \\
\hline & neighbors & & \\
\hline & Noise of children in the garden & 10 & 13.90 \\
\hline & Other & 4 & 5.60 \\
\hline \multirow[t]{4}{*}{ The most annoying noise } & Traffic noise & 48 & 62.30 \\
\hline & $\begin{array}{l}\text { Noise from downstairs and upstairs } \\
\text { neighbors }\end{array}$ & 17 & 22.10 \\
\hline & Noise of children in the site garden & 7 & 9.10 \\
\hline & Other & 5 & 6.50 \\
\hline \multirow[t]{3}{*}{ Most disturbing noise } & Noises in the house & 23 & 29.90 \\
\hline & Noises from outside the house & 45 & 58.40 \\
\hline & Noise is not a problem. & 9 & 11.70 \\
\hline
\end{tabular}




\begin{tabular}{|c|c|c|c|c|}
\hline \multirow{5}{*}{$\begin{array}{l}\text { The extent to which noises in your } \\
\text { home distract someone reading or } \\
\text { studying }\end{array}$} & \multirow[t]{4}{*}{ Not at all } & 1 & 17 & 22.10 \\
\hline & & 2 & 9 & 11.70 \\
\hline & & 3 & 16 & 20.80 \\
\hline & & 4 & 10 & 13.0 \\
\hline & A lot & 5 & 25 & 32.50 \\
\hline \multirow{5}{*}{$\begin{array}{l}\text { The extent to which noise from } \\
\text { outside your home distracts } \\
\text { someone reading or studying }\end{array}$} & \multirow[t]{4}{*}{ Not at all } & 1 & 19 & 24.70 \\
\hline & & 2 & 13 & 16.90 \\
\hline & & 3 & 8 & 10.40 \\
\hline & & 4 & 16 & 20.80 \\
\hline & A lot & 5 & 21 & 27.30 \\
\hline \multirow{3}{*}{$\begin{array}{l}\text { The rate at which sounds from TV } \\
\text { and radio are heard in the room } \\
\text { where your child is studying }\end{array}$} & \multicolumn{2}{|c|}{ It is never heard. } & 24 & 31.20 \\
\hline & \multicolumn{2}{|c|}{ A little audible. } & 47 & 61.0 \\
\hline & \multicolumn{2}{|c|}{ It can be heard easily. } & 6 & 7.80 \\
\hline \multirow{5}{*}{$\begin{array}{l}\text { Frequency of you or your spouse } \\
\text { watching TV/Listening to the radio } \\
\text { while your child is studying in } \\
\text { their room }\end{array}$} & \multicolumn{2}{|c|}{ Never } & 10 & 13.0 \\
\hline & \multicolumn{2}{|l|}{ Rarely } & 27 & 35.10 \\
\hline & \multicolumn{2}{|l|}{ Sometimes } & 27 & 35.10 \\
\hline & \multicolumn{2}{|l|}{ Often } & 8 & 10.40 \\
\hline & \multicolumn{2}{|l|}{ Always } & 5 & 6.50 \\
\hline The rate at which the sounds of & \multicolumn{2}{|c|}{ It is never heard. } & 13 & 16.90 \\
\hline household appliances such as & \multicolumn{2}{|c|}{ A little audible. } & 41 & 53.20 \\
\hline $\begin{array}{l}\text { vacuum cleaner and mixer can be } \\
\text { heard from the child's room. }\end{array}$ & \multicolumn{2}{|c|}{ It can be heard easily. } & 23 & 29.90 \\
\hline Frequency of using household & \multicolumn{2}{|l|}{ Never } & 27 & 35.10 \\
\hline appliances such as vacuum cleaner & \multicolumn{2}{|l|}{ As needed } & 50 & 64.90 \\
\hline $\begin{array}{l}\text { and mixer while your child is } \\
\text { studying in his room }\end{array}$ & \multicolumn{2}{|l|}{ Always } & - & - \\
\hline The rate at which conversations or & \multicolumn{2}{|c|}{ It is never heard. } & 23 & 29.90 \\
\hline phone calls in the house are heard & \multicolumn{2}{|c|}{ A little audible. } & 50 & 64.90 \\
\hline $\begin{array}{l}\text { from the room where your child is } \\
\text { studying }\end{array}$ & \multicolumn{2}{|c|}{ It can be heard easily. } & 4 & 5.20 \\
\hline
\end{tabular}

As can be seen in Table 3, 27 (35.1\%) of the parents who participated in the study reported that they had problems caused by the noise in the house. The rate of those who say that some and most of the noise in the house is caused by children outweighs. This result indicates that children can exhibit noisy behavior at home. As other sources of noise in the house, $36(48 \%)$ of the parents chose the option related to the noise made by their children in the house, and $35(46.7 \%)$ of them chose the option related to the technological tools in the house. As the most disturbing noise, the parents marked the options related to the noises made by the children the most and the technological equipment in the house. $32(41.6 \%)$ of the parents who participated in the research stated that they had problems with noise coming from outside in their homes. This result shows that nearly half of the parents are exposed to noise from outside the home and they live in the noisy area. As external noise, 43 (59.7\%) of the parents marked the traffic noise option. This result shows that parents are most exposed to traffic noise. In addition, the parents who chose the other option indicated house repairs and machine noises as noise sources because 
they live in an industrial area. It is seen that 48 (62.3\%) of the parents marked the traffic noise option as the most disturbing noise. Parents who ticked the other option stated the machine sounds coming from outside as the most disturbing noise source. As the most disturbing noise, 45 (58.4\%) of the parents who participated in the research marked the option of noise coming from outside the home.

As can be seen in Table 3, 25 (32.5\%) of the parents who participated in the research stated that the noises from inside the house distract someone who is reading a book or studying as too much. 21 $(27.3 \%)$ of the parents who participated in the research stated that the noise from outside the house distracts someone who is reading a book or studying as too much. Half of the parents stated that there was so much noise at home that they could not read, and that it was caused by the outside, that is, the traffic. More than half of the parents, 47 (61\%) stated that the sounds coming from the TV, music player and radio can be heard in the room where their child is studying. The fact that only $10(13 \%)$ of the parents participating in the research have never checked the frequency of watching TV/ listening to the radio while their child is studying in their room reveals that the necessary sensitivity is not shown in this regard. Regarding the rate of hearing the sounds made by small household appliances in the room where their child is studying, 41(53.2) of the parents who participated in the research marked the option slightly audible. As the frequency of using small household appliances while their child is studying in his room, 50 (64.9\%) of the parents who participated in the research stated that they use them as needed. Regarding the rate of hearing the conversations or phone calls made in the house from the room where their child is studying, 50 (64.9\%) of the parents who participated in the research stated that they were slightly audible.

\section{Views on the Effects and Control of Noise at Home}

The second sub-problem of the research was determined as "What are the views of parents on the effects of noise exposure at home and its control?". The findings obtained for this problem are given in Table 4.

\section{Table 4}

Views on the Effects and Control of Noise Exposure at Home

\begin{tabular}{|c|c|c|c|}
\hline Items & Options & $\mathrm{f}$ & $\%$ \\
\hline Importance of cutting or reducing & A little important & 11 & 14.30 \\
\hline internal or external noise for your & Important & 28 & 36.40 \\
\hline \multirow[t]{2}{*}{ children } & Very important & 36 & 46.80 \\
\hline & Insignificant & 2 & 2.6 \\
\hline \multirow[t]{5}{*}{$\begin{array}{l}\text { What do you do to deal with or reduce } \\
\text { noise at home? }\end{array}$} & $\begin{array}{l}\text { I speak loudly so that my voice can } \\
\text { be heard. }\end{array}$ & 4 & 5.20 \\
\hline & $\begin{array}{l}\text { I prefer white goods with low noise } \\
\text { level. }\end{array}$ & 9 & 11.70 \\
\hline & $\begin{array}{l}\text { I limit listening to loud TV and } \\
\text { music. }\end{array}$ & 23 & 29.0 \\
\hline & $\begin{array}{l}\text { I pay attention to the rule of speaking } \\
\text { in a low tone without shouting in the } \\
\text { family. }\end{array}$ & 38 & 49.40 \\
\hline & I don't do much. & 3 & 3.90 \\
\hline
\end{tabular}




\begin{tabular}{|c|c|c|c|}
\hline First priority in providing a suitable & Keeping the room clean and tidy & 16 & 20.8 \\
\hline learning environment for the child to & Room smells good & - & - \\
\hline \multirow[t]{3}{*}{ study at home } & To be bright & 7 & 9.10 \\
\hline & The quiet environment & 54 & 70.10 \\
\hline & Suitable room temperature & - & - \\
\hline How often you lower your tone while & Never & 1 & 1.30 \\
\hline studying, chatting, or making phone & Rarely & 9 & 11.80 \\
\hline \multirow[t]{3}{*}{ calls in your child's room } & Sometimes & 13 & 17.10 \\
\hline & Often & 18 & 23.70 \\
\hline & Always & 35 & 46.10 \\
\hline Allowing your child to study at home & Never & 46 & 60.50 \\
\hline while listening to music or while the TV & Rarely & 18 & 23.70 \\
\hline \multirow[t]{2}{*}{ is on } & Sometimes & 11 & 14.50 \\
\hline & Often & 1 & 1.30 \\
\hline Do you have a rule about not speaking & Yes & 61 & 81.30 \\
\hline $\begin{array}{l}\text { loudly and in unison in family } \\
\text { communication? }\end{array}$ & No & 14 & 18.70 \\
\hline Do you have any rules for others to be & Yes & 52 & 68.40 \\
\hline $\begin{array}{l}\text { quiet or speak in a whisper while your } \\
\text { child is studying at home? }\end{array}$ & No & 24 & 31.60 \\
\hline Studying at home by listening to music & I strongly disagree & 9 & 11.80 \\
\hline \multirow[t]{4}{*}{ negatively affects learning. } & I disagree & 7 & 9.20 \\
\hline & I'm undecided & 15 & 19.70 \\
\hline & I agree & 17 & 22.40 \\
\hline & I strongly agree & 28 & 36.80 \\
\hline All kinds of sounds (TV, radio, & I strongly disagree & 1 & 1.30 \\
\hline household appliances such as mixers, & I disagree & 5 & 6.50 \\
\hline chat, phone calls, etc.) that can be heard & I'm undecided & 4 & 5.20 \\
\hline from the room while children are & I agree & 34 & 44.20 \\
\hline studying are noise. & I strongly agree & 33 & 42.90 \\
\hline
\end{tabular}

As seen in Table 4, 36 (46.8\%) of the parents stated the importance of cutting or reducing the noise from inside or outside for their children as very important. In order to cope with or reduce noise at home, 38 $(49.4 \%)$ of the parents who participated in the research answered that they should pay attention to the rule of speaking in a low tone without shouting in the family. As the first priority in providing a suitable learning environment for the child to study at home, 54 (70.1\%) of the parents who participated in the research stated that the environment should be quiet. 35 (46.1\%) of the parents who participated in the research reported that the frequency of lowering the tone of voice while their child is studying, chatting or making phone calls in his room is always. 61 (81.3\%) of the parents who participated in the study reported that they have a rule of not speaking loudly and in unison in family communication. 52 (68.4\%) of the parents reported that while their child is studying at home, the others have a rule about being quiet or speaking in a whisper. Regarding the situation of allowing their child to study at home while listening to music or while the TV is on, 46 (60.5) of the parents who participated in the research selected 
never option. "Studying at home by listening to music negatively affects learning." 28 (36.8\%) of the parents; "While the children are studying, all kinds of sounds that can be heard from their room (TV, radio, household appliances such as mixers, chat, phone calls, etc.) are noise." 33 (842.9\%) of the parents gave the answer that they absolutely agree.

\section{Opinions on the Level and Causes of Noise at School}

The third sub-problem of the study was determined as "What are the parents' views on the level of noise exposure at school and its causes?" The findings obtained for this problem are given in Table 5.

\section{Table 5}

Opinions on the Level and Causes of Noise Exposure at School

\begin{tabular}{|c|c|c|c|}
\hline Items & Options & $\mathrm{f}$ & $\%$ \\
\hline Existence of an important problem caused by & Yes & 32 & 42.10 \\
\hline noise at school & No & 44 & 57.90 \\
\hline \multirow[t]{3}{*}{ The overall noise level of your school } & Low & 7 & 9.50 \\
\hline & Middle & 50 & 67.60 \\
\hline & Very high & 17 & 23.0 \\
\hline \multirow[t]{3}{*}{ Noise level during recess at school } & Low & 2 & 2.70 \\
\hline & Middle & 29 & 39.20 \\
\hline & Very high & 43 & 58.10 \\
\hline \multirow[t]{3}{*}{ Noise level during class at school } & Low & 28 & 37.80 \\
\hline & Middle & 38 & 51.40 \\
\hline & Very high & 8 & 10.80 \\
\hline Students' behavior such as talking loudly, & Whenever they want & 9 & 12.20 \\
\hline playing games, singing, running around in & Rarely & 25 & 33.80 \\
\hline \multirow[t]{2}{*}{ classrooms and corridors } & Often & 20 & 27.0 \\
\hline & Always & 20 & 27.0 \\
\hline Auditory or acoustic comfort of your school's & Very low & 5 & 6.80 \\
\hline \multirow[t]{3}{*}{ classrooms and corridors } & Low & 16 & 21.90 \\
\hline & Normal & 45 & 61.60 \\
\hline & Very good & 7 & 9.60 \\
\hline The rate at which the noise in the school is & Some & 13 & 17.30 \\
\hline \multirow[t]{2}{*}{ made by the students } & The vast majority & 49 & 65.30 \\
\hline & All & 13 & 17.30 \\
\hline \multirow[t]{4}{*}{ Other sources of noise at school } & $\begin{array}{l}\text { Ringtones and } \\
\text { announcements }\end{array}$ & 29 & 41.40 \\
\hline & $\begin{array}{l}\text { Traffic noise from outside the } \\
\text { building }\end{array}$ & 23 & 32.90 \\
\hline & $\begin{array}{l}\text { Broom machine. broken } \\
\text { fluorescent lamps }\end{array}$ & 1 & 1.40 \\
\hline & Other & 17 & 24.30 \\
\hline
\end{tabular}




\begin{tabular}{llrl}
\hline The most important noise problem at school & Noises in the school & 55 & 72.40 \\
& Noise from outside the school 15 & 19.70 \\
& Noise is not a problem & 6 & 7.90 \\
\hline
\end{tabular}

As seen in Table 5, $32(42.1 \%)$ of the parents who participated in the study reported that there is an important problem caused by noise at school. Regarding the general noise level of the school, 50 (67.6\%) of the parents who participated in the research stated that it was medium. Regarding the noise level during recess at school, $43(58.1 \%)$ of the parents who participated in the research stated that it was very high. $38(51.4 \%)$ of the parents who participated in the research stated the noise level during the lesson at school as medium. Twenty $(27 \%)$ of the parents who participated in the research stated that the students' behaviors such as speaking loudly, playing games, singing and running around in the classrooms and corridors were always.

Regarding the auditory or acoustic comfort of the classrooms and corridors of the school, 16 (21.9) of the parents who participated in the research stated that it was low. $49(65.3 \%)$ of the parents who participated in the research stated that the majority of the noise in the school was made by the students. This result shows that most of the noise in the school is made by the students. Regarding other noise sources in the school, $29(41.4 \%)$ of the parents who participated in the research selected the option of ringing tones and announcements. The parents who marked the "other" option listed the other sources of noise in the school, respectively, the noise of factories, factories and construction work, the noises made by other children in the garden during the lesson, the presence of factories around the school, the noise of the students, the noise from the factories around the school, the students who run to the washroom after getting permission from their teacher during the lesson. They stated the sound of running outside the building, construction, etc., factories close to the school building, the sound of students running to the washroom, running after getting permission from their teachers during the lesson, banging on the doors, and the sounds of the factories around the building. As the most important noise problem at school, $55(72.4 \%)$ of the parents who participated in the research marked the option of noise occurring in the school.

\section{Views on the Effects and Control of Noise at School}

The fourth sub-problem of the study was determined as "What are the views of parents on the effects of noise exposure at school and its control?". The findings obtained for this problem are given in Table 6 .

\section{Table 6}

Effects of School Noise Exposure and Views on its Control

\begin{tabular}{llll}
\hline Items & Options & F & $\%$ \\
\hline $\begin{array}{l}\text { My child should be able to freely exhibit } \\
\text { noisy behaviors in the school during recess }\end{array}$ & I disagree & 46 & 61.30 \\
$\begin{array}{l}\text { (such as playing, running, talking loudly, } \\
\text { singing...). }\end{array}$ & I agree & 19 & 25.30 \\
$\begin{array}{ll}\text { The state of being disturbed by the noise of } \\
\text { the child's friends at school }\end{array}$ & 10 & 13.30 \\
& No is & 46 & 62.20 \\
& No idea & 13 & 17.50 \\
& & 15 & 20.30 \\
\hline
\end{tabular}




\begin{tabular}{|c|c|c|c|}
\hline Frequency of school administration and & Rarely & 3 & 4.10 \\
\hline teachers setting limits/rules to prevent & Sometimes & 14 & 19.20 \\
\hline behaviors such as talking loudly, playing & Often & 28 & 38.40 \\
\hline $\begin{array}{l}\text { games, singing, running around in } \\
\text { classrooms and corridors }\end{array}$ & Always & 28 & 38.40 \\
\hline \multirow[t]{5}{*}{ The most disturbing noise at school } & $\begin{array}{l}\text { Noise of students inside the } \\
\text { building }\end{array}$ & 63 & 82.90 \\
\hline & $\begin{array}{l}\text { Traffic noise from outside the } \\
\text { building }\end{array}$ & 7 & 9.20 \\
\hline & Ringtones and announcements & 2 & 2.60 \\
\hline & $\begin{array}{l}\text { Vacuum cleaner. broken } \\
\text { fluorescent }\end{array}$ & 1 & 1.30 \\
\hline & Other & 3 & 3.90 \\
\hline \multirow{3}{*}{$\begin{array}{l}\text { The importance of cutting or reducing the } \\
\text { noise from inside or outside the school }\end{array}$} & Insignificant & 1 & 1.30 \\
\hline & Important & 33 & 43.40 \\
\hline & Very important & 42 & 55.30 \\
\hline Noise pollution at school has negative & I strongly disagree & 5 & 6.60 \\
\hline effects such as tiring students' brains, & I disagree & 1 & 1.30 \\
\hline weakening their thinking power, creating & I'm undecided & 6 & 7.90 \\
\hline distraction, negatively affecting short and & I agree & 22 & 28.90 \\
\hline $\begin{array}{l}\text { long-term memory and decreasing school } \\
\text { success. }\end{array}$ & I strongly agree & 42 & 55.30 \\
\hline \multirow{5}{*}{$\begin{array}{l}\text { School administration and teachers should } \\
\text { prevent behaviors such as talking loudly, } \\
\text { playing games, singing, running around in } \\
\text { the classroom and corridors by setting } \\
\text { certain limits/rules. }\end{array}$} & I strongly disagree & 4 & 5.30 \\
\hline & I disagree & 3 & 3.90 \\
\hline & I'm undecided & 6 & 7.90 \\
\hline & I agree & 22 & 28.90 \\
\hline & I strongly agree & 41 & 53.90 \\
\hline \multicolumn{2}{|c|}{ Students should be able to warn each other I strongly disagree } & 3 & 3.90 \\
\hline when they see behaviors such as talking & I disagree & 1 & 1.30 \\
\hline \multicolumn{2}{|c|}{ loudly, playing games, singing and runningI'm undecided } & 6 & 7.90 \\
\hline \multirow[t]{2}{*}{ around the school. } & I agree & 34 & 44.70 \\
\hline & I strongly agree & 32 & 42.1 \\
\hline \multicolumn{2}{|c|}{ Contribution of school administrators to theYes. I will } & 62 & 81.60 \\
\hline \multicolumn{2}{|c|}{ work they will do to improve the auditory I'm undecided } & 12 & 15.80 \\
\hline \multicolumn{2}{|c|}{ comfort or acoustics of the classroom No. I won't } & 2 & 2.60 \\
\hline \multirow{5}{*}{$\begin{array}{l}\text { The degree of distraction from noises } \\
\text { occurring inside your child's school }\end{array}$} & Not at all & 4 & 5.30 \\
\hline & 2 & 12 & 15.80 \\
\hline & 3 & 16 & 21.10 \\
\hline & 4 & 14 & 18.40 \\
\hline & A lot & 30 & 39.50 \\
\hline
\end{tabular}




\begin{tabular}{lllll}
\hline The degree of distraction from outside & Not at all & 1 & 12 & 15.80 \\
noises, such as traffic, at your child's school & 2 & 15 & 19.70 \\
& & 3 & 17 & 22.40 \\
& A lot & 5 & 10 & 13.20 \\
& & 22 & 28.90 \\
\hline
\end{tabular}

As can be seen in Table 6, "My child should be able to freely play, run, speak loudly, and sing in the classrooms and corridors of the school during breaks." Forty-six (61.3\%) of the parents gave the answer that they disagree. School administration and teachers stated that $28(38.4 \%)$ of the parents who participated in the research always stated the frequency of setting limits/rules in order not to speak loudly, play games, sing, and run around in the classrooms and corridors. Forty-six (62.2\%) of the parents participating in the study stated that they were uncomfortable with the noise of their child's friends at school. As the most disturbing noise at school, 63 (82.9\%) of the parents marked the option of students' noise in the building. Parents who marked the option "Other" stated that the most disturbing noise at school was the noises in the factories, the noises coming from outside the building, and the noises from the factories surrounding the school outside the school.

42 (55.3\%) of the parents who participated in the research marked the answer as very important for the importance of cutting or reducing the noise originating from inside or outside the school. This result shows that parents think that efforts to reduce noise are necessary. "Noise pollution at school has negative effects such as tiring students' brains, weakening their thinking power, creating distraction, negatively affecting short and long-term memory and reducing school success." 42 (55.3\%) of the parents gave the answer that I strongly agree to the item. "School administration and teachers should prevent behaviors such as talking loudly, playing games, singing, running around in classrooms and corridors by setting certain limits/rules." 41 (53.9\%) of the parents gave the answer that they absolutely agree. "Students should be able to warn each other when they see behaviors such as talking loudly, playing games, singing, running around in school." $32(42.1 \%)$ of the parents gave the answer that I strongly agree to the item. $62(81.6 \%)$ of the parents who participated in the study reported that school administrators would contribute to their work to improve the auditory comfort or acoustics of the classroom. Thirty (39.5\%) of the parents reported that the noise level in their child's school was too distracting. $22(28.9 \%)$ of the parents reported that the degree of distraction from outside noises such as traffic in their child's school is too high.

\section{Discussion}

In this section, the results of parents' views on the causes of noise at home and at school, the effects of noise, and the control of noise are presented. It was observed that the majority of the participants included in the study consisted of low or middle socio-economic level parents. The selection of this sample from the public school increases the generalizability of the results of the research, as it represents the majority of the society. More than one-third of the parents stated that their children do not have a study room. Nearly half of them think that noise will cause discomfort, but that it is not harmful to human health. Approximately 15\% stated that they do not set rules about noise at home and these rules are not followed. These results, as stated by Dökmen (2019), lack of definition, which is the first of the dimensions necessary for awareness to occur; that is, it shows a lack of perception about the harms of 
noise and what causes it. In this case, it will be necessary to increase the awareness of the family members so that the children are not affected by the noise, especially while studying. As a result of the lack of awareness, it turns out that parents do not set democratic rules about noise. As a result, the rules on noise only exist for children; while children are studying, it can be thought that parents continue their routines such as watching TV and doing housework. However, the limits and awareness of responsibility for the control of noise, whether at school or at home, should be shared by everyone (Cüceloğlu, 2019c). It will be easier for children to comply with these rules if children's opinions are taken while creating the rules and explanations are made about why these rules are set. Families should be in a relationship that will help children learn the rules about noise (Cloud \& Townsend, 2018).

This result shows the need for parents to be educated about noise awareness and their children to set rules or boundaries at home. More than one third of the parents stated that they face the problem of noise at home. According to the parents' opinions, children make more noise at home. This result again reveals the necessity of parents to create rules about noise at home. In addition, small household appliances have been reported to cause significant noise. Parents should avoid operating devices that cause noise, such as vacuum cleaners and TVs, especially when children are studying. Almost half of the parents stated that the noise from outside the home is at a distracting level. In line with the findings obtained from the study, it is concluded that the houses on the main street with heavy traffic should not be preferred when choosing a house. When parents' noise awareness is low, the noise phenomenon will probably be ignored when choosing a home. For this reason, as underlined by Dökmen (2019), if parents are made aware of the physical stimuli in the environment, it can contribute to creating a more suitable learning environment for children at home.

Research findings show that the noises in their homes are loud enough to distract someone who is reading or studying. At the beginning of the distracting noises are watching TV while the child is studying or using technological devices such as a vacuum cleaner at home, chatting loudly or making phone calls. While some of the parents are aware that these sounds can be heard easily in the child's room, it is seen that the majority of them are not aware of this. These findings are evidence of the low level of awareness and consciousness of parents about sound and noise. This shows that children are open to exposure to noise while studying. This result shows that parents' awareness, awareness and sensitivity levels about sound and noise at home should be increased. Parents should empathize with their children. By establishing empathy, we become aware of other people's inner worlds, and we realize the way the other person sees himself and the world. In this way, a person can perceive himself, other people, all objects in his near and far surroundings, in short, the whole universe, including himself (Dökmen, 2019).

The number of parents who are aware of the importance of reducing or preventing internal or external noise for their children is close to half. On the other hand, the number of parents who do not see noise as a significant problem is significant. In this context, besides the parents who stated that they were paying attention to and trying to prevent the noises in the house while their children were studying, there were also those who stated that they considered this issue unimportant. Considering the negative effects of noise both in our home and in our social life, it is necessary to agree as a society about being calm and to create a common value. "The tree bends when it is wet." As in the saying, it is necessary to focus on this issue with importance and sensitivity, starting from an early age in child education. Since education begins in the family, it is very important to first convey information about noise to parents at home and 
at school. For example, "I limit listening to loud TV and music." The rate of agreement with the statement was determined as $30 \%$. This finding shows that there is a need to increase awareness and awareness on this issue. After completing the questionnaire, many parents came to the researcher and asked, "Are we doing it right?" The fact that they asked, is an indication that they are not sure about what is right and what is wrong. In addition, it was observed that the parents were quite curious, interested and willing to gain information during the survey. This result indicates that even filling out a questionnaire contributes to parents' noise awareness. The fact that parents are curious about and interested in the answers to the questions in the questionnaire is an indication that they are open to improvement in this regard. If the survey questions do not arouse excitement or emotion in the parents, even though they have read it, they will not be curious; In other words, awareness does not emerge (Dökmen, 2019). The fact that parents are excited about this shows that they have an emotional experience, which is one of the requirements for realization.

Findings regarding the attitudes and behaviors of parents at home show that they can exhibit noisy behavior even when their children are studying. For example, most of the parents stated that loud noises in the house could be heard from the child's room; Loud chatting or making phone calls on the phone while the child is studying has emerged as a common behavior. It is difficult for a person who grew up in a noisy environment at home, at school and on the street to perceive the negative effects of noise and to struggle against it. For this reason, in order to combat the noise that has spread to all areas of social life, the awareness of individuals to observe the knowledge, beliefs and values transferred by culture should be activated (Cüceloğlu, 2019c). About one-third of the parents stated that they do not set any rules about being calm while the children are studying and they talk loudly from time to time. This result shows that noisy behavior is common in parents. Anything made to be heard while someone is studying or reading a book is not known to be noise. The level of awareness of parents on this issue shows that they are not even aware of the current situation, which is the first of the awareness dimensions stated by Cüceloğlu (2019d). It is obvious that parents should be informed about the importance of peace at home and setting rules and limits to ensure peace at home. For example, almost $40 \%$ of parents say that they allow their child to study while listening to music at home or while the TV is on. This finding shows that nearly half of the parents do not know that music will have a negative effect on activities such as reading, doing homework, testing or problem solving, other than routine tasks such as table arrangement. All kinds of sounds such as TV, music, mixer, household appliances, chat, phone calls that can be heard from the room while children are studying are noise. Parents should be made aware of this issue and their attitudes, attitudes and actions at home should overlap. If we want to teach children a behavior, we must first set a good example ourselves. Otherwise, the child begins to doubt the validity of the information given and our reliability (Cüceloğlu, 2019a). From the results of the research, it was revealed that the awareness and behavior of parents about sound and noise at home should be changed. Studies should be carried out to adopt the culture of calmness as a value judgment by the society, starting with the families.

The results of the research show that $60 \%$ of the parents are not aware of the noise problem at school, regarding the existence of a significant problem caused by noise at school. This is where it becomes clear how important and necessary it is to be aware. By becoming aware, our consciousness level about ourselves, our environment and the universe increases, and our field of consciousness expands (Dökmen, 2019). $40 \%$ of parents find the noise level ( $85 \mathrm{~dB}$ ) occurring during recess at school to be 
medium or low. However, studies on this subject report that the noise level in school breaks is high (Tamer Bayazit et al., 2011; Bulunuz et al., 2017b). Nearly 90\% of the parents see the noise level that occurs during the lesson at school as medium and low. Previous studies show that the noise level at school has reached twice the limit levels determined in the regulation (Bulunuz et al., 2017c; Özbıçakçı et al., 2012; Tamer Bayazit et al., 2011). Parents reported that the noise level during class at school was lower than during recess. The lower noise level here is due to the effect of the teacher's presence in the classroom.

As a result of the findings obtained from the research, it was revealed that the school did not have a specific rule about noise or a policy to manage noise at school. More than half of the parents are aware of their children's discomfort with the noise at school; but about the other half are unaware of it. These results show us that some of the parents have awareness and knowledge on this issue; shows that some of them are not aware of this issue or have incomplete and incorrect information. As Dökmen (2019) stated, noticing physical stimuli in our environment can contribute to our existence more effectively. In order to learn and adapt to the outside world, it is necessary to notice first. For this reason, first of all, studies should be carried out to prepare and distribute awareness-raising brochures about noise for the purpose of informing parents to eliminate this difference of opinion; Collaboration should be made with parents who will give support in this regard, in the creation and implementation of rules on noise prevention. More detailed ideas can be obtained by conducting one-on-one interviews with parents.

The majority of parents (more than 70\%) consider the acoustic comfort in the school building to be good and normal. However, researches in the field show that most of the school buildings are built without taking acoustic measures and the noise level is well above the limit values. This result shows that the expectation of acoustic comfort of parents is very low or their knowledge on this subject is incomplete. It may not be perceived as a very important problem for parents, as noise is not seen, does not smell, and does not pollute the air and water (Bulunuz et al., 2017a). Therefore, the negative effects of noise on the quality of education may have been overlooked. $80 \%$ of the parents stated that the most disturbing noise at school was caused by the behavior of the students. According to Ikenbergy (1974), there are two main causes of noise pollution at school; the first reason is the noisy behavior of the students (As cited in Bulunuz et al., 2017a). This result shows that the majority of parents are aware of student-induced noise at school. In order to prevent the noise in the school, it is necessary to follow the students more closely and cooperate with the parents regarding the compliance with the rules. Hollingsworth and Hoover (1999) see parents as children's teachers at home, as they directly or indirectly educate children at home. For this reason, as stated by Şimşek and Tanaydın (2002), home and school should complement and integrate each other for an effective school education.

The findings show that the majority of parents are aware that noise is a disturbing situation. However; it is noteworthy that about $20 \%$ of them are not aware of the negative effect of noise on learning. $98 \%$ of parents think that reducing the noise level is very important. This result shows that parents think that efforts to reduce noise are necessary. The majority of parents are students of teachers at the time of noise; while we think that the students should warn each other and prevent the noise; about $20 \%$ of them are undecided or disagree about curbing noisy behaviors. While the majority of parents agree that students should warn each other's noisy behaviors, approximately one-fifth of them do not. Parents need to agree on something like noise pollution at school. For example, more than half of parents find noise in school distracting, while nearly $40 \%$ are unaware of it. Even as to the degree of distraction from 
outside noise, parents have varying opinions. This again shows that parents are not even aware of the current situation, which is the first of the awareness dimensions explained by Cüceloğlu (2019d). In order for a quiet school and home culture to be formed, all or almost all of the parents must agree on this issue. Since the transition from a noisy school culture to a quiet school culture requires restructuring, such a cultural change is long-term in nature and must therefore be carefully planned and executed. Undoubtedly, it is school principals and teachers who will lead and do this. The administrator of a school has the power to affect teachers, students and their families (Cüceloğlu, 1998).

The findings show that there is a need to raise awareness of parents who do not have knowledge and awareness about the importance of noise and acoustic improvement at school. Acoustic design and poor sound insulation are among the factors that increase noise pollution in schools (Aydın, 1998). In order for school buildings to be a healthy, productive working and living space, acoustic comfort should be given importance in all steps from design to operation. Because children spend most of their lives in schools and are more vulnerable to noise than adults (Roy, 2011 cited in Bulunuz, et al., 2017a). The second author, who is also a teacher, observed that noise is an issue with many unknowns for parents. Creating awareness and awareness in this regard, both through surveys and informational trainings, is an important need for controlling noise in schools. In the interviews conducted by the researcher with the parents, the parents who participated in the study reported that they realized that they needed to behave more consciously with their children from now on.

This is the first study on parents' opinions about noise at home and at school. On paper or rhetorically, the importance of school-family cooperation for education is emphasized almost everywhere. The result of this study reveals that there is a need for schools and families to come together to solve a basic problem such as noise at school. In future studies, parents can be trained on noise pollution and comparative research can be conducted before and after education. The opinions of the stakeholders in the school can be evaluated by making acoustic improvement in the whole or in certain parts of the school with the cooperation of the school and the family. Every work to be done will contribute to filling the gap in the literature in this field. All these studies will contribute to the sprouting of a quiet life, learning environments and culture in school and social life, starting with the family.

\section{Acknowledgment}

We thank the room mothers and class representatives who voluntarily participated in the study. Special thanks to Atacan Bulunuz for translating the abstract of the study from Turkish to English, and Ordinaryus Prof.Dr. Olga S. Jarrett for proof reading.

\section{Compliance of ethical standard statement}

In this study, all the rules stated in the scope of "Higher Education Institutions Scientific Research and Publication Ethics Directive" were followed. None of the actions specified under the title of "Actions Contrary to Scientific Research and Publication Ethics", which is the second part of the directive, have been taken.

\section{Ethics committee permission information}

Name of the committee that made the ethical evaluation = Bursa Uludağ University Research and Publication Ethics Committees 
Date of ethical review decision $=03$ July 2020

Ethics assessment certificate issue number

Number of Sessions $=2020-04$

Decision $\mathrm{No}=9$

\section{References}

Aydın, A. (1998). Sınıf yönetimi. Anı Yayıncılık.

Alp, G., Bulunuz, N. Onan, B., \& Bulunuz, M. (2019). Noise map of my school: A case study. Uludağ Üniversitesi Ĕ̆itim Fakültesi Dergisi, 32(2), 379-402. https://doi.org/10.19171/uefad.679310

Bulunuz, N. (2014). Noise pollution in Turkish elementary schools: Evaluation of noise pollution awareness and sensitivity training. International Journal of Environmental \& Science Education, 9(2), 215-234. https://doi.org/10.12973/ijese.2014.212a

Bulunuz, M., Bulunuz, N., \& Kelmendi-Tuncal, J. (2017a). Akustik iyileştirme yapılmış bir okulda gürültü düzeyinin değerlendirilmesi. Eğitimde Kuram ve Uygulama, 13(4), 637 - 658. https://doi.org/10.17244/eku.347793

Bulunuz, N., Bulunuz, M., Orbak, A. Y., Mutlu, N., \& Tavşanlı, Ö. F. (2017b). An evaluation of primary school students' views about noise levels in school. International Electronic Journal of Elementary Education, 9(4), 725-740. https://www.iejee.com/index.php/IEJEE/article/view/281

Bulunuz, N., \& Bulunuz, M. (2017). Noise pollution in school and evaluation of its control through educational practices. In H. Arslan, C. D. Duse, \& M. A. Icbay (Eds.), Research on Education (pp. 320-329). International Association of Social Science Research (IASSR).

Bulunuz, M., Bulunuz, N., Tavşanlı, Ö.F., Orbak, A.Y., \& Mutlu, N. (2018). İlkokullarda gürültü kirliliğinin düzeyi, etkileri ve kontrol edilmesine yönelik sınıf öğretmenlerinin görüşlerinin değerlendirilmesi. Kastamonu Education Journal, 26(3), 661-671. https://doi.org/10.24106/kefdergi.412246

Bulunuz, M., Orbak, A. Y., \& Bulunuz, N. (2018). Okulda gürültü kirliliği: nedenleri, etkileri ve kontrol edilmesi. TÜBİTAK 1001-114k738 nolu proje. Accessed on 13.08 .2021 from https://app.trdizin.gov.tr/proje/TVRnd01USXk/okulda-gurultu-kirliligi-nedenleri-etkileri-vekontrol-edilmesi

Bulunuz, M., Özgür, K., \& Akan, R. (2019). Öğrenme ortamlarında ses ve gürültü düzeyi hakkında ebeveynlere yönelik anket geliştirme süreçlerinin değerlendirilmesi (2587-2600). EJER Tam Metin Bildiri Kitabı, Anı Yayıncilik.

Büyüköztürk, Ş., Çakmak, E. K., Akgün, Ö. E., Karadeniz, Ş., \& Demirel, F. (2016). Bilimsel araştırma yöntemleri. Pegem Atıf İndeksi.

Cloud, H., \& Townsend, J. (2018). Çocuklarda Sınırlar (1. Basım). (B. S. Haktanır, Çev.) Koridor Yayınları. 
Coşkun, Y. (2021). Öğretmen görüşleri bağlamında okullarda gürültü kirliliği sorunsalı, teknolojik ve eğitsel çözüm önerileri. Itobiad: Journal of the Human $\mathcal{E}$ Social Science Researches, 10(1), 207-230. http://www.itobiad.com/en/download/article-file/1422631

Cüceloğlu, D. (1998). İçimizdeki biz (7. Basım). Remzi Kitabevi.

Cüceloğlu, D. (2016). Başarıya götüren aile (13. Basım). Remzi Kitabevi.

Cüceloğlu, D. (2019a). İletişim donanımları (59. Basım).Remzi Kitabevi.

Cüceloğlu, D. (2019b). Insan ve davranışı: Psikolojinin temel kavramları (37. Basım). Remzi Kitabevi.

Cüceloğlu, D. (2019c). Savaşçı (62. Basım). Remzi Kitabevi.

Cüceloğlu, D. (2019d). Gerçek özgürlük (10. Basım). Remzi Kitabevi.

Çetinkaya, F., Bulduk, İ., İşci, D., \& Demir, A. (2017). Okul öncesi öğretmenlerin gürültü maruziyeti. Uşak Üniversitesi Ĕ̆itim Araştırmaları Dergisi, 3(2), 1-14. https://doi.org/10.29065/usakead.290371

Dawkins, R. (1995). Gen bencildir (1. Basım). (Çev. A. Ü. Müftüoğlu). TÜBİTAK Yayınları. (Orijinal eserin basım tarihi, 1976)

Dewey, J. (2017). Okul ve toplum (5. Baskı). (Çev. H. A. Başman). Pegem Akademi. (Orijinal eserin basım tarihi, 1929)

Dockrell, J. E., \& Shield, B. (2004). Children's perceptions of their acoustic environment at school and at home. The Journal of the Acoustical Society of America, 115(6), 2964-2973. https://doi.org/10.1121/1.1652610

Dökmen, Ü. (2019). Evrenle uyumlaşma sürecinde var olmak, gelişmek, uzlaşmak (21. Basım). Remzi Kitabevi.

Goines, L. (2008). The importance of quiet in the home: Teaching noise awareness to parents before the infant is discharged from the NICU. Neonatal Network, 27(3), 171-176. https://doi.org/10.1891/0730-0832.27.3.171

Hollingsworth, P. M., \& Hoover, K. H. (1999). İlköğretimde öğretim yöntemleri (Çev. T. Gürkan, E. Gökçe, \& D. S. Güler). Ankara Üniversitesi Rektörlüğü Yayınları.

Klatte, M., Hellbrück, J., Seidel, J., \& Leistner, P. (2010). Effects of classroom acoustics on performance and well-being in elementary school children: A field study. Environment and Behavior, 42(5), 659-692. https://doi.org/10.117710013916509336813

Mesleki Eğitim ve Öğretim Sisteminin Güçlendirilmesi Projesi (MEGEP). (2006). Türkiye'nin başarısı için itici güç: Hayat boyu öğrenme politika belgesi.

Milli Eğitim Bakanlığı (2014). Örgün ve yaygın eğitimi destekleme ve yetiştirme kursları yönergesi. Accessed on 13.08.2021 from https://www.meb.gov.tr/meb_iys_dosyalar/2014_10/01060217_mebdesteklemeveyetistirmekurs lariyonergesi.pdf 
Özbıçakçı, F. Ş., Çapık, C., Gördes, N., Ersin, F., \& Kıssal, A. (2012). Bir okul toplumunda gürültü düzeyi tanılaması ve duyarlılık eğitimi. Eğitim ve Bilim, 37(165), 238-245. https://eb.ted.org.tr/index.php/EB/article/view/1242/425

Polat, S., \& Buluş-Kırıkkaya, E. (2004, Temmuz, 6-7). Gürültünün eğitim-öğretim ortamına etkileri. XIII. Ulusal eğitim bilimleri kurultayı, İnönü Üniversitesi, Malatya, Türkiye.

Regulation on the Protection of Buildings Against Noise [Binaların Gürültüye Karşı Korunması Hakkındaki Yönetmelik]. (2017). T.C. Resmi Gazete, 30082, 31 May 2017. Accessed on 13.08.2021 from http://www.resmigazete.gov.tr/eskiler/2018/05/20180531-2.htm

Seyidoğlu, H. (2000). Bilimsel araştırma ve yazma el kitabı (8. Basım). Güzem Yayınları.

Sezgin, S., \& Mutlu, A. (2017). Ülkemizde gürültü farkındalığı sorunu: Şişli örneği. Gazi Üniversitesi Iktisadi ve Idari Bilimler Fakültesi $\quad$ Dergisi, 19(2), https://doi.org/10.26745/gaziuiibfd.418599

Shield, B. M., \& Dockrell, J. E. (2003). The effects of noise on children at school: A review. Building Acoustics, 10(2), 97-116. https://doi.org/10.1260/135101003768965960

Shield, B., \& Dockrell, J. (2004). External and internal noise surveys of London primary schools. Journal of the Acoustical Society of America, 115(2), 730-738. https://doi.org/10.1121/1.1635837

Shield, B., \& Dockrell, J. (2006). Acoustical barriers in classrooms: The impact of noise on performance in the classroom. British Educational Research Journal, 32(3), 509-525. https://doi.org/10.1080/01411920600635494

Şimşek, H., \& Tanaydın, D. (2002). İlköğretimde veli katılımı: Öğretmen-veli-psikolojik danışman üçgeni. Elementary Education Online, 1(1), 12-16. https://dergipark.org.tr/en/download/article$\underline{\text { file/91128 }}$

Tamer-Bayazıt, N., Küçükçifçi, S., \& Şan, B. (2011). İlköğretim okullarında gürültüden rahatsızlığın alan çalışmalarına bağlı olarak saptanması. İstanbul Teknik Üniversitesi Dergisi, 10(2), 169-181.

TDK (2020). Türk dil kurumu sözlükleri. Accesed on 05.07.2021 from https://sozluk.gov.tr/

Tüzel, S. (2013). Sınıf içi gürültünün öğrencilerin dinleme sürecindeki bilişsel performansına etkisi/Effects of classroom background noise on cognitive performance of listening process in secondary school students. Eğitimde Kuram ve Uygulama, 9(4), 363-378. https://dergipark.org.tr/en/download/article-file/63386

Yılmaz, E., \& Öznacar, B. (2016). Veli, ebeveyn-anne baba ve okul. In E. Yılmaz, A. Ünal, M. Çalışkan, \& S. A. Sulak (Eds.), Eğitim bilimlerinden yansımalar (pp. 59-70). Konya: Çizgi Kitabevi.

Vijayalakshmi, K. S. (2003). Noise pollution. In J. M. Bunch, V. M. Suresh, \& T. V. Kumaran (Eds.), Proceedings of the Third International Conference on Environment and Health (pp. 597 - 603). Department of Geography, University of Madras and Faculty of Environmental Studies, York University. 
APPENDIX

SOUND AND NOISE IN LEARNING ENVIRONMENTS

PARENT SURVEY

Dear Parents,

Your answers to this questionnaire will be used to investigate parental views on sound and noise at home and at school. Answering the survey questions sheds light on the factors that underlie your child's school success. In this context, you will have an idea about what kind of learning environment should be provided to your child at home and at school in order to increase the academic success of your child. It is very important that you answer the research questions sincerely and accurately. Put an $(X)$ mark on the option that best suits you. Please do not leave any questions unanswered.

TÜBİTAK (1001) Project Numbered114K738

Project Manager: Prof. Dr. Mizrap BULUNUZ

\section{GENERAL INFORMATION FORM}

1. Your gender? Female ( ) Male ( ) 2. Your age? $(\ldots)$

3. Your marital status: Married ( ) Divorced ( ) 4. Number of children: ( )

5. Your education status: Illiterate ( ) Literate ( ) Primary school ( )

Elementary ( ) Middle School ( ) High school ( )

College ( ) Bachelor ( ) Graduate ( )

6. Your working status: Public sector employee ( ) Self-employment ( ) Housewife ( )

Private sector employee ( ) Not working ( ) Other ( )

7. Monthly income level of your family? Low ( ) Medium ( )

Good ( ) Very good ( )

8. Do you have any rules about volume when speaking in family? Yes ( ) No ( )

9. Who sets the rules at home more?

Me ( ) My wife ( ) My wife and I ( ) Children, my wife and I ( )

10. Are the rules at home followed by everyone? Yes ( ) No ( )

11. Does your child have their own room? Yes ( ) No ( )

12. Does your child study in his own room? Yes ( ) No ( )

13. Do you think you have created a suitable study environment for your child at home? Yes ( ) No( )

14. Noise disturbs but does not harm human health. Disagree ( ) Undecided ( ) Agree ( ) 


\subsection{NOISE RESOURCED FROM THE HOUSE}

1.1. Have you ever had a problem caused by the noise in your home?

$\square$ Yes

$\square$ No

1.2. How much of the noise in the house is made by children?

$\square$ None

$\square$ Some

$\square$ The vast majority

$\square$ All

1.3. Please specify other sources of noise in your home.

$\square$ Noises made by children in the house

$\square$ Refrigerator, air conditioner, washing machine, dishwasher

$\square \mathrm{TV}$, computer, aquarium, clock,

$\square$ Other (Please write.)

1.4. What do you think is the most disturbing noise? (Choose only one.)

$\square$ Noises made by children in the house

$\square$ Refrigerator, air conditioner, washing machine, dishwasher

$\square \mathrm{TV}$, computer, aquarium, clock,

$\square$ Other (Please write.)

\subsection{NOISE ORIGINED FROM OUTSIDE THE HOME}

2.1. Are you having trouble with outside noise in your home?

$\square$ Yes

$\square$ No

2.2. What are external noises?

$\square$ Traffic noise

$\square$ Noise from downstairs and upstairs neighbors

$\square$ Noise of children in the site garden

$\square$ Other (Please write.)

2.3. What do you think is the most disturbing noise? (Choose only one.)

$\square$ Traffic noise 
$\square$ Noise from downstairs and upstairs neighbors

$\square$ Noise of children in the site garden

$\square$ Other (Please write.)

\subsection{DEALING WITH NOISE}

3.1. How important do you think it is to cut or reduce internal or external noise for your children?

$\square$ Not important

$\square$ Somewhat important

$\square$ Important

$\square$ Very important

3.2. What noise bothers you the most?

$\square$ Noises in the house

$\square$ Noises from outside the house

$\square$ Noise is not a problem.

3.3. Indicate the extent to which noises in your home distract someone reading or studying.

$$
\text { Not at all } 12345 \text { A lot }
$$

3.4. Indicate the extent to which noise from outside your home distracts someone reading or studying.

Not at all $12345 \quad$ A lot

3.5. What do you do to deal with or reduce noise at home?

$\square$ I speak loudly so that my voice can be heard.

$\square$ I prefer white goods with low noise level.

$\square$ I limit listening to loud TV and music.

$\square$ I pay attention to the rule of speaking in a low tone without shouting in the family.

$\square$ I don't do much.

$\square$ Other (Please write.)

3.6. What do you think is the first priority in providing a suitable learning environment for the child to study at home?

$\square$ Keeping the room clean and tidy

$\square$ The room smells good

$\square$ Being bright

$\square$ Quiet environment 


\section{$\square$ Proper room temperature}

3.7. What is the rate at which sounds from TV, music player and radio can be heard in the room where your child is studying?

$\square$ Not heard at all.

$\square$ Slightly audible.

$\square$ It can be heard easily.

3.8. How often do you or your spouse watch TV / listen to the radio while your child is studying in his room?

$\square$ Never

$\square$ Rarely

$\square$ Occasionally

$\square$ Often

$\square$ Always

3.9. What is the rate at which the sounds of household appliances such as vacuum cleaner and mixer can be heard in the room where your child is studying?

$\square$ Not heard at all.

$\square$ Slightly audible.

$\square$ It can be heard easily.

3.10. How often do you use household appliances such as vacuum cleaner and mixer while your child is studying in his room?

$\square$ Never

$\square$ As needed

$\square$ Always

3.11. What is the rate at which conversations or phone calls made at home are heard from the room where your child is studying?

$\square$ Not heard at all.

$\square$ Slightly audible.

$\square$ It can be heard easily.

3.12. How often do you lower your voice tone while studying, chatting or making phone calls in your child's room?

$\square$ Never

$\square$ Rarely 
$\square$ Occasionally

$\square$ Often

$\square$ Always

3.13. Do you have a rule about not speaking loudly and in unison in family communication?

$\square$ Yes

$\square$ No

3.14. Do you have any rules for others to be quiet or speak in a whisper while your child is studying at home?

$\square$ Yes

$\square$ No

3.15. Do you allow your child to study at home while listening to music or while the TV is on?

$\square$ Never

$\square$ Rarely

$\square$ Occasionally

$\square$ Often

$\square$ Always

3.16. Studying at home by listening to music negatively affects learning.

$\square$ Strongly disagree

$\square$ I slightly disagree

$\square$ I'm undecided

$\square$ I agree

$\square$ I strongly agree

3.17. All kinds of sounds (TV, radio, household appliances such as mixers, chat, phone calls, etc.) that can be heard from the room while children are studying are noise.

$\square$ Strongly disagree

$\square$ I disagree

$\square$ I'm undecided

$\square$ I agree

$\square$ I strongly agree 


\subsection{SOUND AND NOISE AT YOUR CHILD'S SCHOOL}

4.1. Is there a significant problem caused by noise in the school?

$\square$ Yes

$\square$ No

4.2. What do you think of the overall noise level of your school?

$\square$ Low

$\square$ Medium

$\square$ Too high

4.3. What do you think about the noise level during recess at school?

$\square$ Low

$\square$ Medium

$\square$ Too high

4.4. What do you think about the noise level in the school during the lesson?

$\square$ Low

$\square$ Medium

$\square$ Too high

4.5. What is the status of students in behaviors such as talking loudly, playing games, singing, running around in classrooms and corridors?

$\square$ Never

$\square$ Anytime

$\square$ Rarely

$\square$ Often

$\square$ Always

4.6. My child should be able to show behaviors such as playing freely, running, talking loudly and singing in the classrooms and corridors of the school during recess.

$\square$ I disagree

$\square$ I fold a little

$\square$ I agree

4.7. How many limits/rules do the school administration and teachers set in classrooms and corridors to prevent behaviors such as talking loudly, playing games, singing, running around?

$\square$ Never 
$\square$ Rarely

$\square$ Occasionally

$\square$ Often

$\square$ Always

4.8. How would you evaluate your school's classrooms and corridors in terms of auditory or acoustic comfort?

$\square$ Too low

$\square$ Low

$\square$ Normal

$\square$ Very good

4.9. To what extent is the noise in the school made by the students?

$\square$ None

$\square$ Some

$\square$ The vast majority

$\square$ All

4.10. Is your child bothered by the noise of his friends at school?

$\square$ Yes

$\square$ No

$\square$ No idea

4.11. Please indicate other sources of noise in the school.

$\square$ Ringtones and announcements

$\square$ Traffic noise from outside the building

$\square$ Vacuuming machine, broken fluorescent lamps,

$\square$ Other (Please write.)

4.12. What do you think is the most disturbing noise at school? (Please choose one.)

$\square$ Noises made by students inside the building (running, talking loudly, door slamming)

$\square$ Traffic noise from outside the building

$\square$ Ringtones and announcements

$\square$ Vacuuming machine, broken fluorescent lamps

$\square$ Other (Please write.)

4.13. What do you think is the most important noise problem at school? 
$\square$ Noise in school

$\square$ Noise from outside the school

$\square$ Noise is not a problem.

4.14. How important do you think it is to cut or reduce noise from inside or outside the school?

$\square$ Not important

$\square$ Important

$\square$ Very important

4.15. Noise pollution at school has negative effects such as exhausting students' brains, weakening their thinking power, creating distraction, negatively affecting short and long-term memory and decreasing school success.

$\square$ Strongly disagree

$\square$ I disagree

$\square$ I'm undecided

$\square$ I agree

$\square$ I strongly agree

4.16. School administration and teachers should prevent behaviors such as talking loudly, playing games, singing, running around in the classroom and corridors by setting certain limits/rules.

$\square$ Strongly disagree

$\square$ I disagree

$\square$ I'm undecided

$\square$ I agree

$\square$ I strongly agree

4.17. Students should be able to warn each other when they see behaviors such as talking loudly, playing games, singing and running around the school.

$\square$ Strongly disagree

$\square$ I disagree

$\square$ I'm undecided

$\square$ I agree

$\square$ I strongly agree

4.18. Can you contribute to the work of school administrators to improve the auditory comfort or acoustics of the classroom?

$\square$ Yes, I will. 
$\square$ I'm undecided

$\square$ No, I won't.

4.19. Tick the degree of distraction of noises occurring inside your child's school.

Not at all $12345 \mathrm{~A}$ lot

4.20. Tick the degree of distraction from outside noises, such as traffic, at your child's school.

Not at all $12345 \mathrm{~A}$ lot 